\section{Kidney \\ Blood Pressure \\ Research}

\title{
Prof. Jiří Heller
}

Let us share our thoughts on Prof. Jiř́ Heller who deceased after a long, serious disease in Prague on February 23, 2001.

Prof. Heller graduated from Charles University School of Medicine in 1956 and went to work as a lecturer at the Institute of Physiology (where he had been a research student in the renal physiology laboratory since 1952). In 1962, he presented his thesis which earned him a PhD degree. The thesis, entitled 'On the mechanism of reflexmediated changes in diuresis', predicted the existence of atrial natriuretic factor and well reflected his talent for a career in science and experimental work. Regrettably, for political reasons, the thesis appeared only in the Czech language and never received worldwide publicity.

After his forced departure from the medical school, he took the position of researcher at the Institute of Occupational Hygiene and Disease focusing his attention, between 1962 and 1966, on the mechanism of elimination of heavy metals by the kidney. In 1965, he spent a year as a fellowship student at the Department of Physiology, Free University in Berlin, Germany, mastering the technique of renal tubule micropuncture.

Upon his return, he took the offer from Prof. Jan Brod to join the Institute for Circulatory Disease (which merged with other institutes in 1971 to form the Institute for Clinical and Experimental Medicine) and founded a laboratory of renal physiology where he actually worked until his death. It was in that laboratory that Prof. Heller introduced micropuncture techniques and carried out research into the regulation of renal hemodynamics. His pioneering work in this field won him international renown and his papers, published mainly in Pflüger's Archiv, make up an integral part of the basics of renal physiology. Teaming up with his wife in the early 1980s, they bred a new model of the genetically hypertensive rat, referred to as the Prague hypertensive rat (PHR). The model is unique in that both the hypertensive and normotensive (Prague normotensive rat, PNR) lines originate from the same mating couple. The issue of hypertension became another main topic of research projects con-

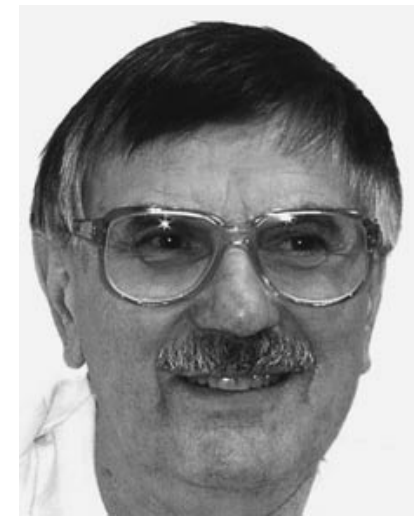

ducted by Prof. Heller; he initiated a number of pioneering projects (particularly in the field of transplant medicine) clearly demonstrating that hypertension in PHR 'travels' with the kidney, a finding which gave rise to the theory on the role played by the kidney in the development of hypertension.

Prof. Heller worked in the laboratory and enjoyed performing experiments on his own. He loved the process of learning and getting to understand the way things actually work. He was also an excellent opponent, always seeking to help and getting to the core of the matter. However, he could be fairly blunt to clearly unprofessional and incompetent individuals, and never hesitated to let the person involved know. He never wasted his time in unfruitful discussions. Prof. Heller simply loved giving lectures and teaching medical students. He was the supervisor of several students during their postgraduate education programs and there is no doubt that some of them will carry on his research. He was a leader and a man of integrity who worked in his laboratory until the last minute, despite his losing battle with disease.

We will all miss his charming personality, intellect, and his sense of humor.

Jan Maly, Ota Schück, Luděk Červenka Institute of Clinical and Experimental Medicine, Prague

\begin{tabular}{ll}
\hline KARGER & ( ) 2001 S. Karger AG, Basel \\
Fax +4161306 1234 & 1420-4096/01/0243-0141\$17.50/0 \\
$\begin{array}{l}\text { E-Mail karger@karger.ch } \\
\text { www.karger.com }\end{array}$ & $\begin{array}{l}\text { Accessible online at: } \\
\text { www.karger.com/journals/kbr }\end{array}$
\end{tabular}

